\title{
DDR1 promotes breast tumor growth by suppressing antitumor immunity
}

\author{
XING ZHONG $^{1^{*}}$, WEIWEI ZHANG ${ }^{2 *}$ and TIANHAO SUN ${ }^{3}$ \\ ${ }^{1}$ Department of Chemotherapy, Jiangxi Cancer Hospital; ${ }^{2}$ Department of Surgery, Jiangxi Health Vocational College, \\ Nanchang, Jiangxi 330006; ${ }^{3}$ Department of Orthopaedics and Traumatology, Li Ka Shing Faculty of Medicine, \\ The University of Hong Kong, Hong Kong, SAR, P.R. China
}

Received February 15, 2019; Accepted August 7, 2019

DOI: $10.3892 /$ or.2019.7338

\begin{abstract}
Breast cancer is the second leading cause of cancer-associated mortality among women worldwide. Triple-negative breast cancer (TNBC) accounts for $15-20 \%$ of all breast cancers and is defined by its aggressive nature and limited treatment options. Therefore, there is an urgent need to develop effective therapies for TNBC in order to improve breast cancer outcomes, as targeted therapies have done in other subtypes of breast cancer. Discoidin domain receptor tyrosine kinase 1 (DDR1) is activated by collagens, which are important components of the tumor stroma; therefore, DDR1 may serve a critical role in the communication between tumor cells and the tumor microenvironment. The aim of the present study was to determine how tumor DDR1 regulated tumor growth by affecting tumor infiltrated T cells. First, the DDR1 expression levels from a cohort of patients with breast cancer were analyzed. The results revealed that there were higher levels of DDR1 expression in tumor tissues compared with adjacent normal tissues. Overexpression of DDR1 in 4T1 cells promoted tumor growth in vivo, while knockout of DDR1 in EMT6 cells decreased tumor growth in vivo. In addition, it was revealed that DDR1 regulated tumor growth by modulating tumor infiltrating $\mathrm{T}$ cells, $\mathrm{CD}^{+}$and $\mathrm{CD}^{+}$. Furthermore, inhibition of DDR1 by neutralizing antibodies decreased breast cancer growth in vivo. To the best of our knowledge, the results of the present study demonstrated for the first time that DDR1 expressed on the tumor cells promoted breast tumor growth by suppressing antitumor immunity. The present findings indicated that DDR1 may not
\end{abstract}

Correspondence to: Dr Xing Zhong, Department of Chemotherapy, Jiangxi Cancer Hospital, 519 Beijingdong Road, Nanchang, Jiangxi 330006, P.R. China

E-mail: smilezx_777@126.com

${ }^{*}$ Contributed equally

Key words: discoidin domain receptor tyrosine kinase 1, breast cancer, tumor growth, $\mathrm{CD}^{+} \mathrm{T}$ cell, $\mathrm{CD} 8^{+} \mathrm{T}$ cells, extracellular domain only have a critical role in the progression of breast cancer, but may also serve as a potential therapeutic target for breast cancer, particularly TNBC.

\section{Introduction}

Breast cancer is the second most common cancer worldwide and, by far, the most frequent cancer among women (1). Approximately $15-20 \%$ of all patients with breast cancer are diagnosed with triple-negative breast cancer (TNBC), named after its lack of estrogen receptor alpha $(\mathrm{ER} \alpha)$, progesterone receptor (PR) and epidermal growth factor receptor 2 (HER2) expression (2). While several treatment options are available to treat $\mathrm{ERa}^{+}$and HER2-driven breast cancers, options are somewhat limited for patients with TNBC, who cannot take advantage of these targeted therapies. There is therefore a pressing clinical need to identify novel drug targets and therapeutic strategies for women with TNBC. Recent years have witnessed major clinical breakthroughs in cancer immunotherapies, which include cancer peptide vaccines, dendritic cell vaccines, adoptive transfer of cytotoxic T lymphocytes (CTL) and blockade of immune-suppressive checkpoint molecules (3-8). However, despite success with immunotherapies in treating melanoma and lung cancer, breast cancer has proven to be particularly difficult to treat with checkpoint blockade or other immunotherapies (9-13). The current clinical trials for patients with TNBC utilizing checkpoint-blockade immunotherapy have demonstrated only modest efficacy (14).

Discoidin domain receptor tyrosine kinase (DDR) 1 is a cell-surface tyrosine kinase, which can be activated by collagens, and regulates cell growth, adhesion, migration and matrix remodeling. DDR1 is predominantly expressed in normal epithelial cells and its aberrant expression in a variety of human cancers is associated with tumor progression, including breast, lung, ovary, liver, gastric cancer and glioma (15-21). Accumulating evidence has revealed DDR1 mutations in breast cancer, schwannoma, endometrial cancer, lung cancer and acute leukemia (22-26). Since DDR1 is being considered as a potential novel therapeutic target in cancer, defining its precise function during breast cancer progression is of critical importance for the development of associated therapies alone and in combination with immunotherapy. 
In the present study, to further investigate the role of DDR1 in breast cancer progression and to validate DDR1 as a novel target for breast cancer therapy, two murine breast cancer cell lines, 4T1 and EMT6, were used to mimic human TNBC. It was demonstrated that DDR1 was frequently upregulated in patients with breast cancer. Furthermore, it was revealed that tumor cell DDR1 promoted breast cancer growth in vivo by modulating CTLs. Lastly, inhibition of DDR1 by using a specific extracellular domain (ECD) neutralizing antibody decreased breast cancer growth and increased CTL tumor infiltration in vivo.

\section{Materials and methods}

Patients and tissue samples. A total of 30 samples of breast cancer tissues and adjacent tissues were surgically removed from patients (age range, 37-56 years) in Jiangxi Cancer Hospital between March 2013 and December 2016. Ethical approval for the present study was provided by the Ethics Committee of Jiangxi Cancer Hospital. Written informed consent was obtained from all the study participants.

Bioinformatic analysis. For analysis of gene expression, The Cancer Genome Atlas (TCGA) BRCA datasets were downloaded from TCGA (https://tcga-data.nci.nih.gov) (27). UALCAN, an easy to use, interactive web-portal was used to analyze DDR1 mRNA gene expression in the breast cancer datasets (28).

Mice, cell lines and chemicals. A total of 32 female BALB/c mice (age, 6-8 weeks; weight, 22-28 g) were obtained from the Animal Center of the Chinese Academy of Medical Sciences (Beijing, China). Mice were provided with free access to food, water and bedding at all time, and were housed in filter top cages (maximum 5 mice per cage) at $21-23^{\circ} \mathrm{C}$ with $45-55 \%$ humidity and a 12 -h light/dark cycle. All animal experiments were performed in accordance with the National Institute of Health Guide for the Care and Use of Laboratory Animals, with the approval of the Ethics Committee of Jiangxi Cancer Hospital. Mouse mammary cancer cell lines 4T1 and EMT6, derived from the BALB/c mouse strain, were obtained from the American Type Culture Collection and maintained in RPMI-1640 medium (Gibco; Thermo Fisher Scientific, Inc.) supplemented with $10 \%$ fetal bovine serum (FBS; Hyclone Laboratories; GE Healthcare Life Sciences), 1\% penicillin/streptomycin (Invitrogen; Thermo Fisher Scientific, Inc.) at $37^{\circ} \mathrm{C}$ in $5 \% \mathrm{CO}_{2}$.

Plasmid transfection. The full-length cDNA of mouse DDR1 (NM_172962.1; 2,625 bp) cloned in the pCMV3 backbone vector (cat. no. MG50829-UT) was obtained from Sino Biological, Inc. 4T1 cells $\left(2 \times 10^{5}\right.$ cells in $\left.2 \mathrm{ml}\right)$ were seeded into a 6-well plate, one day prior to transfection. A total of $5 \mu \mathrm{g}$ DDR1-expressing plasmid DNA or empty vector, with $10 \mu 1$ Lipofectamine ${ }^{\circledR} 2000$ reagent (Invitrogen; Thermo Fisher Scientific, Inc.) in $200 \mu \mathrm{l}$ Opti-MEM ${ }^{\circledR}$ medium, was added into each well. After $6 \mathrm{~h}$, the transfection medium was replaced with fresh medium. After 72 h, 4T1-DDR1 cells and control 4T1-vector cells were selected with $500 \mu \mathrm{g} / \mathrm{ml}$ hygromycin for 1 week.
CRISPR/Cas9-mediated knockout (KO) of mouse DDR1. DDR1-deficient cells were generated using the CRISPR/Cas9 system, in order to investigate the role of DDR1 in the interactions between immune cells and mammary tumor cells. The target sequences for mouse DDR1 were: i, GCAGCAGCAGTAGAGATGAG; and ii, GCAGTGATG GAGATGGGGCT. The sequences for DDR1 were selected using the CRISPR MultiTargeter tool (http://www.multicrispr. net/) (29) and off-targets were excluded using GT-Scan tools (30). Oligonucleotides with BsmB1 restriction sites for guide RNAs were synthesized by SBS Genetech Co., Ltd., then phosphorylated using T4 kinase (31). The phosphorylated oligonucleotides were cloned into LentiCRISPR v2 (Plasmid no. 52961; Addgene) and the sequences of the cloned plasmids that were extracted from numerous selected colonies were confirmed by SBS Genetech Co., Ltd. EMT6 cells were transfected with pLentiCRISPR-single guide RNA (sgRNA) DDR1 using Lipofectamine ${ }^{\mathrm{TM}} 2000$ (Invitrogen; Thermo Fisher Scientific, Inc.), according to the manufacturer's protocol. The cells were cultured with $1 \mu \mathrm{g} / \mathrm{ml}$ puromycin for 2 weeks, starting at 3 days post-transfection. Single cells were then sorted by fluorescence-activated cell sorting (FACS) into 96-well plates. The depletion of DDR1 in the surviving cells was validated via western blotting. $\mathrm{KO} 1$ and $\mathrm{KO} 2$ clones were from two independent sgRNA sequences of mouse DDR1.

$R N A$ extraction and reverse transcription-quantitative $P C R(R T-q P C R)$. Total RNA was extracted using TRIzol ${ }^{\circledR}$ (Thermo Fisher Scientific, Inc.). Reverse transcription reactions were performed using M-MLV reverse transcriptase (Promega Corporation). For mRNA detection, DDR1 and GAPDH mRNA expression levels were analyzed using Luminaris Color HiGreen qPCR Master Mix (Thermo Fisher Scientific, Inc.), according to the manufacturer's protocol (Applied Biosystems; Thermo Fisher Scientific). The following primers were used: GAPDH, forward 5'-GACTCA TGACCACAGTCCATGC-3' and reverse 5'-AGAGGCAGG GATGATGTTCTG-3'; DDR1, forward 5'-GATTTCCCCTTA ATGTGCGT-3' and reverse 5'-TGGCATCTGGCCGTAAGA TC $-3^{\prime}$. Relative gene expression was calculated by the $2^{-\Delta \Delta C q}$ method (32).

Western blotting. The cells were washed twice with phosphate buffered saline (PBS) and lysed in ice-cold radio immunoprecipitation assay buffer (RIPA; Beyotime Institute of Biotechnology) with freshly added $0.01 \%$ protease inhibitor PMSF (Amresco) and incubated on ice for $20 \mathrm{~min}$. The total cell protein was collected by centrifugation at $10,000 \mathrm{x} \mathrm{g}$ for $10 \mathrm{~min}$ at $4^{\circ} \mathrm{C}$. Protein concentrations were determined using a Bradford assay (Bio-Rad Laboratories, Inc.). Total protein $(30 \mu \mathrm{g})$ from each sample were separated via SDS-PAGE (10\% gel) and electrophoretically transferred onto a polyvinylidene difluoride membrane (EMD Millipore). The immunoblots were blocked by incubation in 5\% skimmed milk, $25 \mathrm{mM}$ Tris (hydroxymethyl) aminomethane- $\mathrm{HCl}$ (pH 8.0), $150 \mathrm{mM} \mathrm{NaCl}$, and $0.1 \%$ Tween $^{\circledR} 20$ for $1 \mathrm{~h}$ at $25^{\circ} \mathrm{C}$. Membranes were incubated with the following primary antibodies: DDR1 (1:1,000; cat. no. sc-532; Santa Cruz Biotechnology, Inc.), DDR1 (1:1,000; cat. no. AF2396; R\&D Systems, Inc.), and $\beta$-actin (1:10,000; cat. no. sc-47778; 
Santa Cruz Biotechnology, Inc.), followed by the corresponding horseradish peroxidase-conjugated secondary antibodies (1:10,000; cat. nos. 115-035-003 and 111-035-003; Jackson ImmunoResearch Laboratories, Inc.). Protein detection was performed using an enhanced chemiluminescence kit (ECL; Thermo Fisher Scientific, Inc.).

Cell Counting Kit-8 (CCK-8) cytotoxicity assay. The proliferation of cells was measured using a CCK-8 cytotoxicity assay (Dojindo Molecular Technologies, Inc.). EMT6 or 4T1 cells were seeded in 96-well plates at a density of 2,000 cells/well and cultured with RPMI-1640 medium containing 10\% FBS. CCK-8 solution $(20 \mu \mathrm{l})$ was added to each well, and the plates were incubated for $2 \mathrm{~h}$ at $37^{\circ} \mathrm{C}$ at the indicated time points. The optical density levels were measured using a microplate reader scanning at $450 \mathrm{~nm}$ according to the manufacturer's protocol.

Detection of released DDR1 extracellular domain in the media. EMT6 cells were washed twice with warm PBS, and the cell monolayers were incubated $\left(37^{\circ} \mathrm{C}\right)$ in serum-free media for another $24 \mathrm{~h}$. The conditioned media were then collected and clarified by a spin at $10,000 \mathrm{x} \mathrm{g}$ for $10 \mathrm{~min}$ at $4^{\circ} \mathrm{C}$ to remove cell debris. The supernatants were supplemented with EDTA to a final concentration of $2 \mathrm{mM}$, before a high-speed centrifugation $\left(20,000 \mathrm{x} \mathrm{g}, 30 \mathrm{~min}, 4^{\circ} \mathrm{C}\right)$ to remove cell membranes and vesicles. A total of $200 \mu \mathrm{l}$ of each media were then precipitated with trichloroacetic acid (24), and the resultant pellets were washed with acetone and resuspended in 2x reducing Laemmli SDS-sample buffer. The immunoblots were probed with antibody AF2396 (as aforementioned), which is directed against the $\mathrm{N}$-terminal region of DDR1.

In vivo tumor studies. The tumor cells in log phase growth were centrifuged at $500 \mathrm{x}$ g for $5 \mathrm{~min}$ at room temperature, washed once with Hank's balanced salt solution (HBSS), counted, and re-suspended in HBSS with 50\% Matrigel (BD Biosciences) at a concentration of $5 \times 10^{5}$ cells $/ \mathrm{ml}$ (4T1) or $1 \times 10^{6}$ cells/ml (EMT-6). Cell suspensions $(100 \mu \mathrm{l})$ were injected subcutaneously near the fourth mammary gland fat pad. The mice were acclimated to the study conditions for at least 1 week prior to tumor cell implantation. The animals were randomly distributed into treatment groups (5 mice per group) and treated with mouse immunoglobulin (Ig) G1 isotype control (cat. no. BE0093; Bio X Cell), or anti-DDR1 (mouse IgG1 clone 5D5; cat. no. MABT333; EMD Millipore; $200 \mu \mathrm{g} /$ mouse intraperitoneally twice per week for 4 weeks). Tumors were measured once per week using a caliper, and tumor volumes were calculated using the modified ellipsoid formula $1 / 2 \times$ (length $\mathrm{x}$ width ${ }^{2}$ ).

Preparation of single cell suspension and antibody staining for flow cytometry. The tumors were collected, weighed and enzymatically digested using a cocktail of dispase (Thermo Fisher Scientific, Inc.), collagenase P (Roche Diagnostics) and DNaseI (Roche Diagnostics) (33) for $45 \mathrm{~min}$ at $37^{\circ} \mathrm{C}$, to obtain a single cell suspension. Cells were counted using a Vi-CELL XR (Beckman Coulter, Inc.). For T-cell staining, cells were first incubated with mouse BD Fc block (1:100; clone 2.4G2; cat. no. 553141; BD Biosciences) and LIVE/DEAD ${ }^{\circledR}$ Fixable Dead Cell Stain (Invitrogen; Thermo Fisher Scientific, Inc.) for $30 \mathrm{~min}$ on ice. The cells were then stained for $30 \mathrm{~min}$ on ice with the following antibodies: Anti-CD45-BV605 (cat. no. 563053; clone 30-F11; 1:200; BD Biosciences), anti-CD3e-FITC (cat. no. 553061; clone 145-2C11; 1:100; BD Biosciences), anti-CD8-PerCP (cat. no. 100732; clone 53-6.7; 1:50; BioLegend, Inc.), anti-CD4-BV711 (cat. no. 100557; clone RM4-5; 1:200; BioLegend, Inc.) and anti-CD69-APC (cat. no. 104514; clone H1.2F3; 1:25; BioLegend, Inc.). For intracellular staining, the cells were washed with $1 \mathrm{ml}$ PBS, and incubated for $30 \mathrm{~min}$ at $4^{\circ} \mathrm{C}$ with the surface marker antibodies. After washing, cells were fixed and permeabilized with fixation concentrate and permeabilization diluent (eBioscience) and stained in 10X permeabilization buffer (eBioscience) for the intracellular proteins, according to the manufacturer's protocol. The following antibodies were used for $30 \mathrm{~min}$ at room temperature in the dark: Anti-Ki67-PE antibody (cat. no. 652404; clone 16A8; 1:50; BioLegend, Inc.) and anti-T-box transcription factor 21 (also known as T-bet)-PE-Cy7 (cat. no. 644824; clone 4B10; 1:100; eBioscience). Flow cytometry data were collected with a BD LSRFortessa cell analyzer and analyzed using FlowJo Software (version 10.2; FlowJo LLC).

Statistical analysis. Data were analyzed using GraphPad Prism software (version 6; GraphPad Software, Inc.) and are presented as the mean \pm standard deviation. Two-tailed Student's t-tests were used to compare two groups, and one-way ANOVA followed by Dunett's test was used to compare multiple groups. $\mathrm{P}<0.05$ was considered to indicate a statistically significant difference.

\section{Results}

DDR1 is frequently upregulated in breast cancer. RT-qPCR analyses were performed to determine the expression levels of DDR1 in 20 primary breast cancer samples and their matched adjacent normal tissues. The results demonstrated that the mRNA expression levels of DDR1 were significantly higher in tumor tissues compared with the matched adjacent tissues (Fig. 1A). Further analysis of DDR1 expression levels using the TCGA breast cancer database revealed that DDR1 was expressed at higher levels in breast cancer samples compared with normal samples (Fig. 1B). In addition, DDR1 mRNA expression levels were higher in different subtypes (luminal, HER $2^{+}$and triple negative), compared with those in the normal breast tissues (Fig. 1C). Furthermore, the protein expression levels of DDR1 were examined by western blotting in another 10 primary breast cancer samples. The results demonstrated that the protein expression of DDR1 was also markedly increased in the breast cancer tissues collected in the present study compared with their matched adjacent normal tissues (Fig. 1D). Overall, these data demonstrated that DDR1 was upregulated in breast cancer.

Ectopic expression of DDR1 promotes tumor growth in vivo by suppressing antitumor immunity. Consistent with previously published results (34), mouse mammary tumor cells 
A

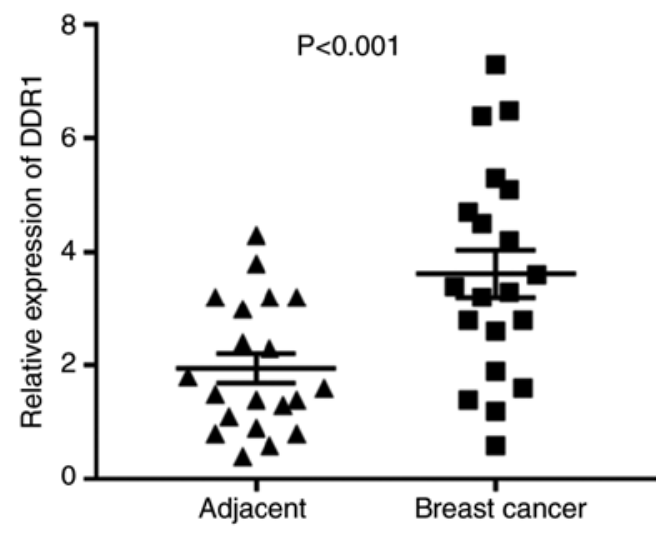

C

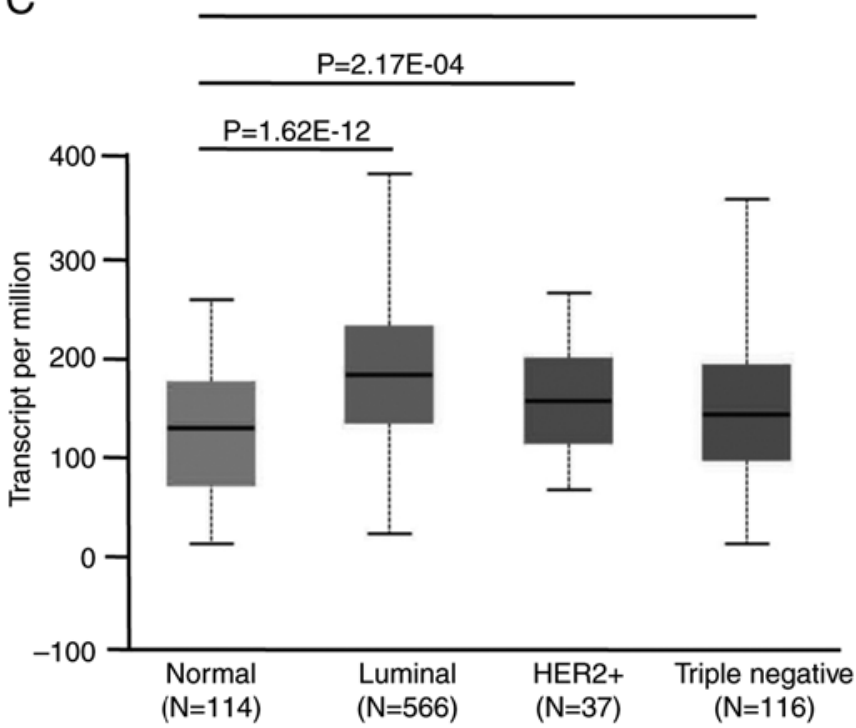

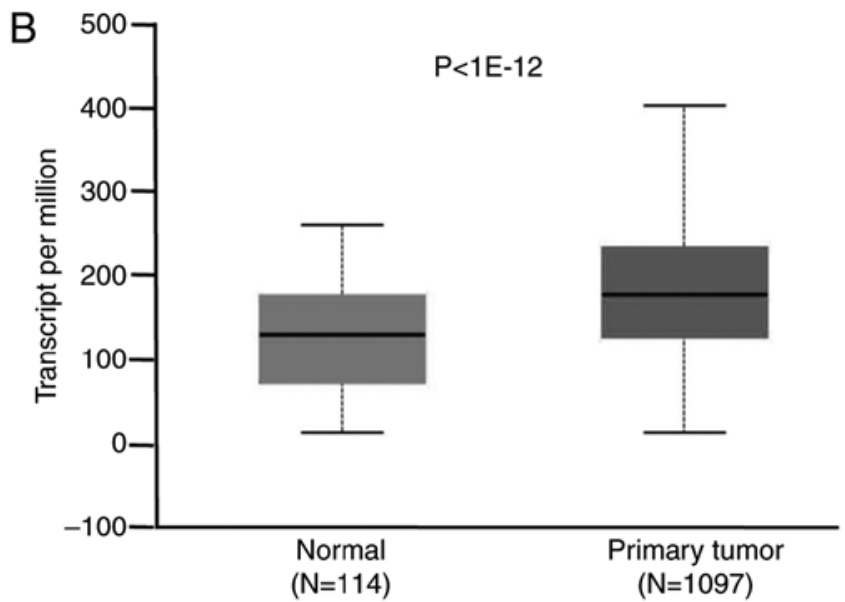
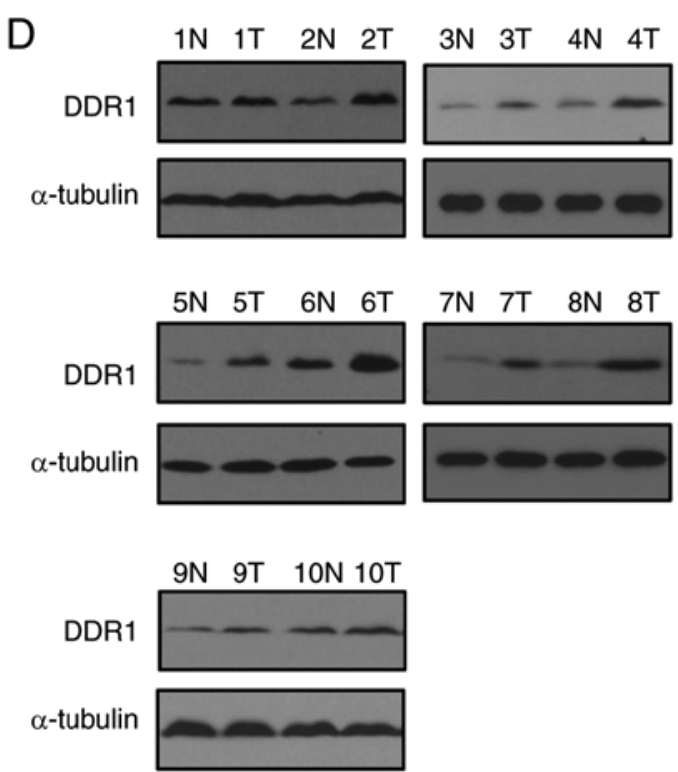

Figure 1. Upregulation of DDR1 in breast cancer. (A) Reverse transcription-quantitative PCR was used to examine the mRNA levels of DDR1 in breast cancer tissues compared with adjacent non-tumor tissues from 20 patients enrolled in the present study. (B and C) Mean expression levels of DDR1 in TCGA breast cancer datasets. (D) The protein expression levels of DDR1 were detected by western blot analysis in 10 pairs of breast cancer tissues and adjacent non-tumor tissues. Values are presented as the mean \pm standard error of the mean. DDR1, discoidin domain receptor tyrosine kinase 1; TCGA, The Cancer Genome Atlas; HER2, epidermal growth factor receptor 2; $\mathrm{N}$, normal; $\mathrm{T}$, tumor.

4T1/Vector (4T1 cells stably transfected with empty vector) expressed undetectable levels of endogenous DDR1 protein. In order to determine whether DDR1 could affect tumor cell growth, mouse DDR1 was transfected into 4T1 cells and stable cells overexpressing DDR1 were obtained (Fig. 2A). The effects of DDR1 overexpression on the cell proliferation were then investigated using a CCK-8 assay. It was revealed that overexpression of DDR1 did not affect cancer cell growth in vitro (Fig. 2B). To further investigate the effects of DDR1 on tumor cell growth in vivo, a tumorigenesis assay was performed in $\mathrm{BALB} / \mathrm{c}$ female mice using $4 \mathrm{~T} 1$ cells with or without stable DDR1 overexpression. The tumors in the 4T1/DDR1 group grew faster compared with the 4T1/Vector group $(\mathrm{P}<0.01$; Fig. $2 \mathrm{C}$ and $\mathrm{D})$. These results suggested that high DDR1 expression in breast cancer may be associated with a more aggressive state. When investigating models for immuno-oncology purposes, it is also important to know the composition of infiltrated immune cells into a tumor. To this end, it was demonstrated that there was a lower percentage of
$\mathrm{CD} 4^{+}$and $\mathrm{CD} 8^{+} \mathrm{T}$ cells in the tumors of the $4 \mathrm{~T} 1 / \mathrm{DDR} 1$ group compared with those in the $4 \mathrm{~T} 1 /$ Vector group $(\mathrm{P}=0.014$ and $\mathrm{P}=0.037$, respectively; Fig. 2E and F).

Deletion of DDR1 inhibits tumor growth in vivo. To further elucidate the role of DDR1 in breast cancer cell growth, DDR1-deficient EMT-6 cell lines were established using the CRISPR/Cas9 system using two different sgRNA sequences (Fig. 3A). DDR1 KO clone 1 has a 'AG' insertion, which created a stop codon shortly after initiation (Fig. 3B). DDR1 KO clone 2 deletes four nucleotides 'GGGC' and results in a frame shift in the DDR1 coding sequence (Fig. 3B). DDR1 KO did not affect tumor cell growth in vitro (Fig. 3C). Notably, the tumors derived from the KO1 clone of EMT-6 cells regressed completely after they reached $\sim 100 \mathrm{~mm}^{3}$ $(\mathrm{P}<0.0001$; Fig. 3D and $\mathrm{E})$. The tumors derived from the $\mathrm{KO} 2$ clone grew dramatically slower in the $\mathrm{BALB} / \mathrm{c}$ hosts compared with those in the control group $(\mathrm{P}<0.0001$; Fig. 3D and E). Taken together, DDR1 expression in the 

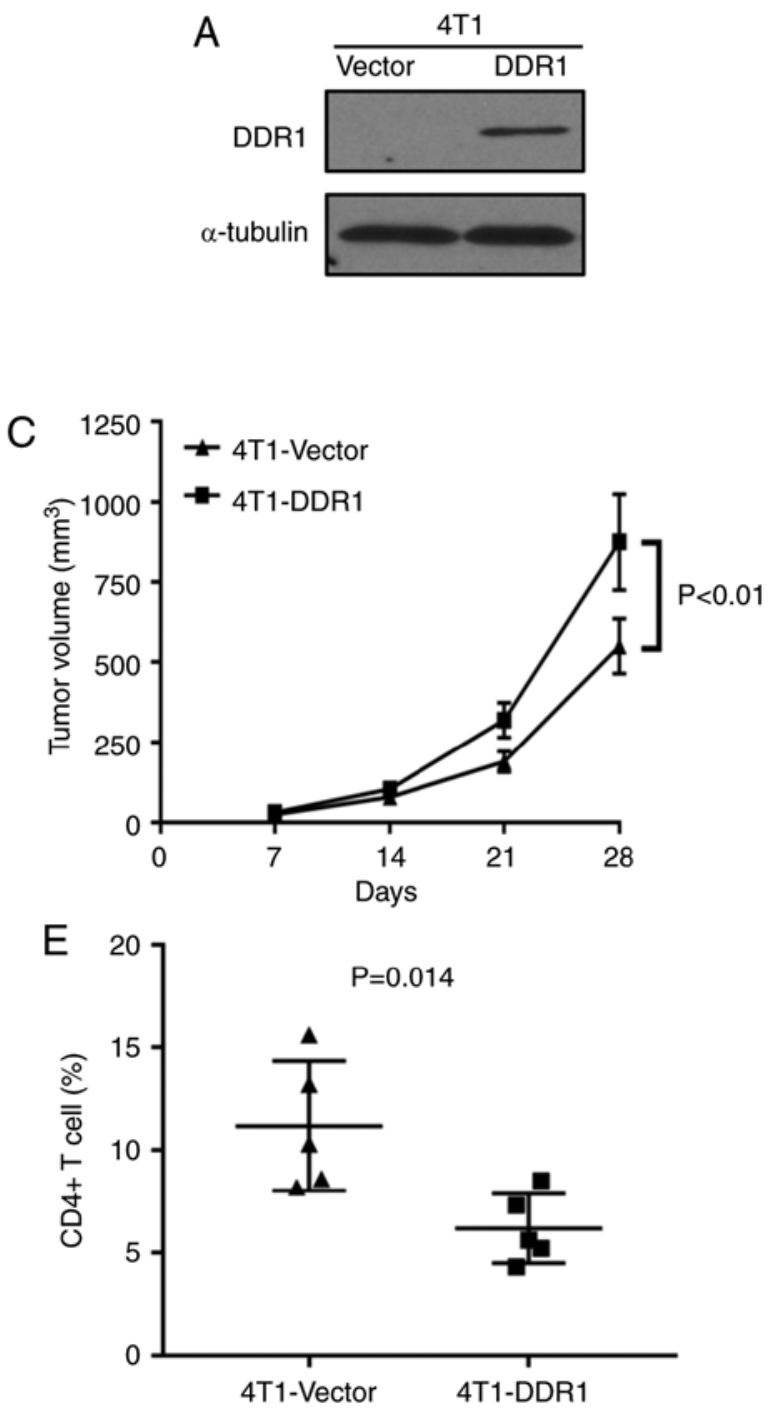
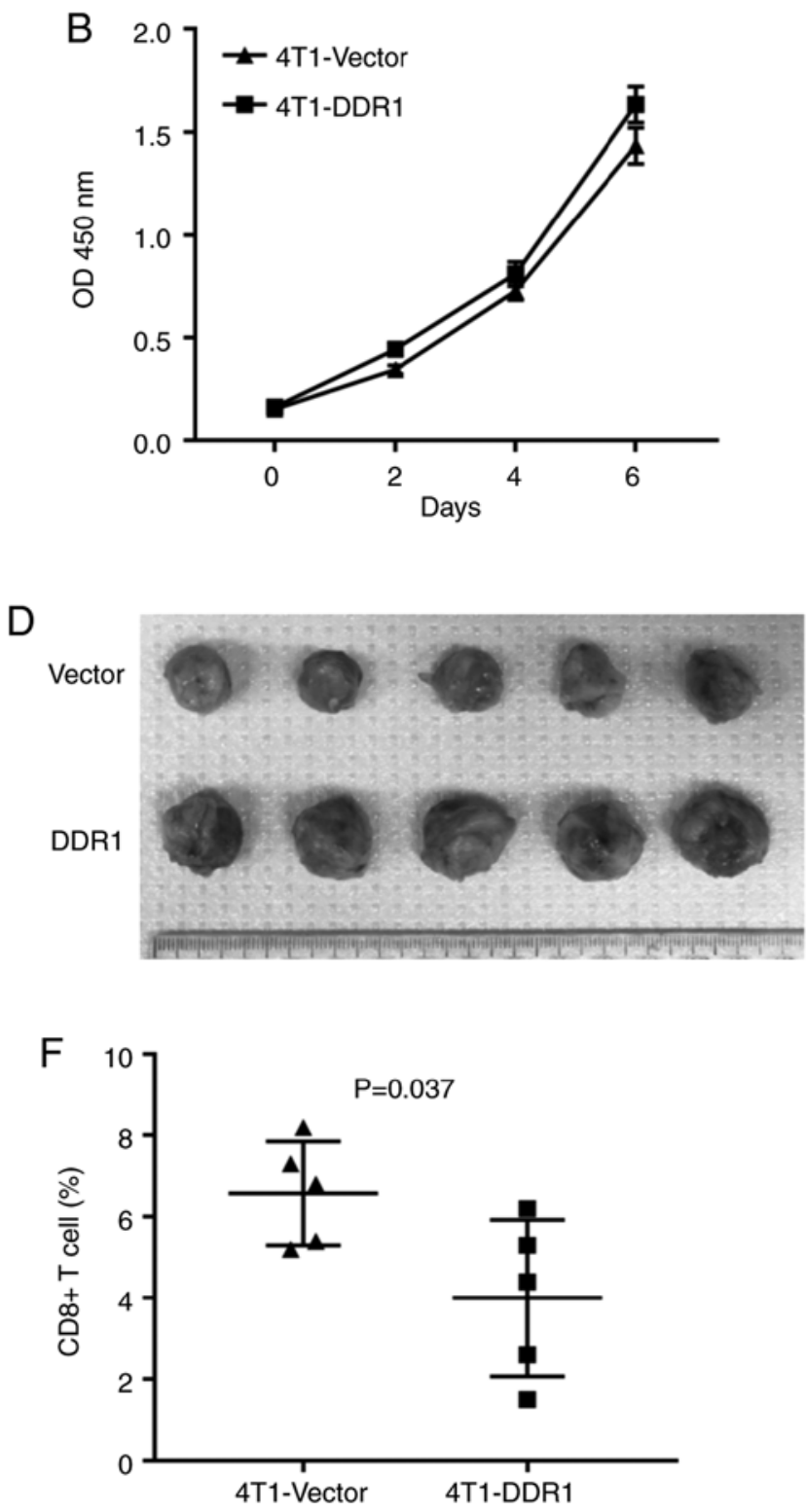

Figure 2. Ectopic expression of DDR1 promotes tumor growth in vivo. (A) Western blot analysis of DDR1 protein expression levels following stable overexpression of DDR1 in 4T1 cells compared with vector control. (B) In vitro cell proliferation assay was performed with 4T1 vector control and DDR1-overexpressing cells. (C) In vivo tumorigenesis assay was performed with the 4T1 vector control and DDR1-overexpressing 4T1 cells. Tumor volumes and (D) photographs are shown ( $n=5$ per group). (E) Flow cytometry analysis of dissociated tumors ( $n=5$ per group) for $\mathrm{CD}^{+}{ }^{+}$and $(\mathrm{F}) \mathrm{CD}^{+}$infiltrating $\mathrm{T}$ cells. DDR1, discoidin domain receptor tyrosine kinase 1; OD, optical density.

tumor cells was demonstrated to be important for sustained breast tumor growth in vivo.

Cytotoxic $T$ cells mediate the tumor-promoting activity of DDR1. In order to examine the influence of tumor cell DDR1 on antitumor immunity, the tumors derived from EMT-6/Control and EMT-6/KO2 groups were collected, and tumor-infiltrating lymphocytes (TILs) were assessed via flow cytometric analysis. The results demonstrated that the percentage of $\mathrm{CD}^{+}$and $\mathrm{CD}^{+}$TILs was significantly increased $(\mathrm{P}=0.042$ and $\mathrm{P}=0.025$, respectively; Fig. $4 \mathrm{~A}$ and $\mathrm{B}$ ) in the tumors derived from the EMT-6 DDR1 KO2 cells compared with the tumors derived from the EMT-6/Control cells. DDR1 KO2-derived tumors also exhibited increased density of early activated and proliferating $\mathrm{CD}^{+} \mathrm{T}$ cells relative to control tumors $(\mathrm{P}=0.03$ and $\mathrm{P}=0.035$, respectively; Fig. $4 \mathrm{C}$ and D). In addition, DDR1
$\mathrm{KO} 2$-derived tumors had increased density of T-bet expressing $\mathrm{CD}^{+}$TILs compared with control tumors ( $\mathrm{P}=0.017$; Fig. 4E). T-bet, a T-box transcription factor, serves an important role in $\mathrm{T}$ cell differentiation and maturation $(35,36)$. These data indicated that tumor DDR1 promoted breast cancer growth by modulating antitumor immunity.

DDRl inhibition suppresses tumor growth in vivo by enhancing antitumor $T$ cell activity. Structurally, DDR 1 consists of an ECD, a transmembrane domain and an intracellular kinase domain (37-40). A recent study revealed that DDR1 had a kinase-independent function in promoting breast cancer growth (41). Secreted soluble DDR1-ECD has been reported in a number of previous studies (42-44), but its biological significance in cancer has not yet been elucidated. For these reasons, the present study first investigated whether 


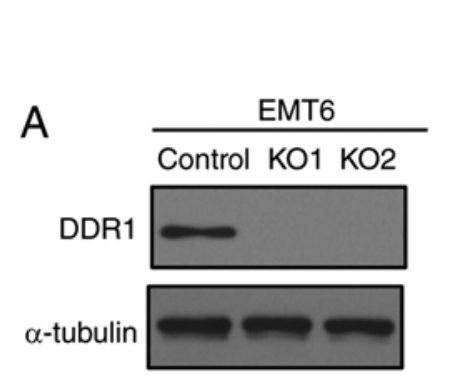

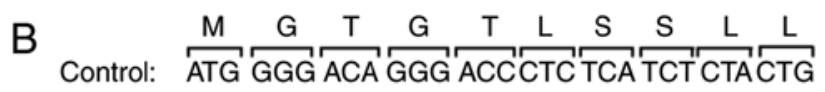

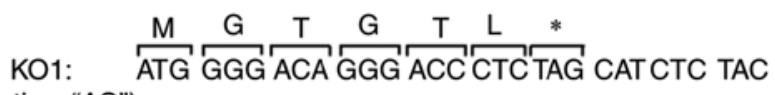
(insertion: "AG")

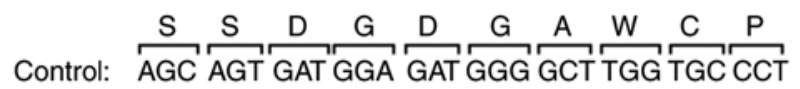

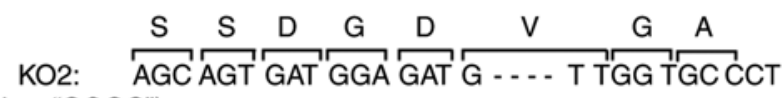

(deletion: "GGGC")
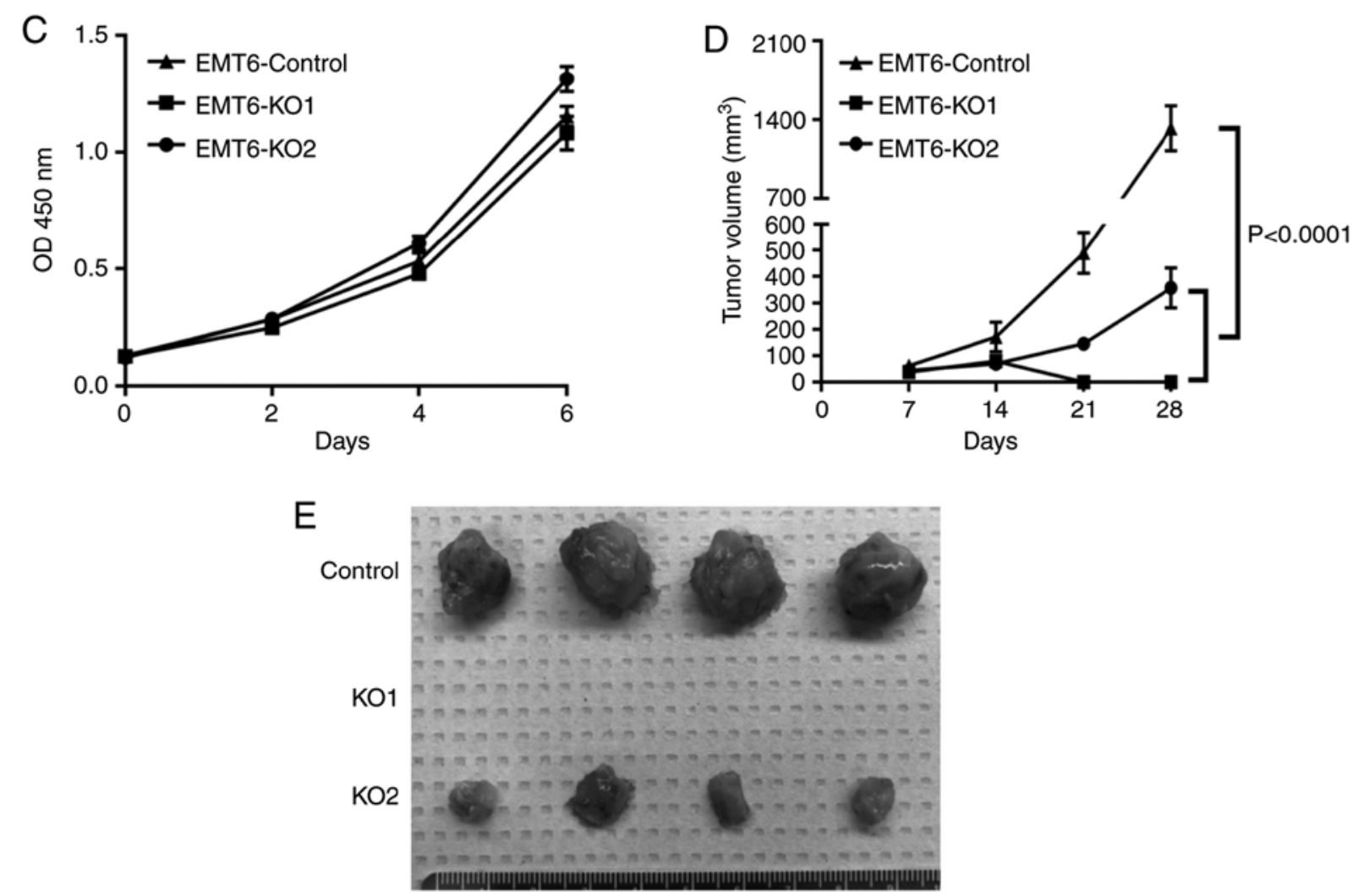

Figure 3. Deletion of DDR1 inhibits tumor growth in vivo. (A) Establishment of DDR1 KO EMT6 cell lines using the CRISPR/Cas9 method. Western blotting revealed that DDR1 expression was obviously depleted in DDR1 KO1 and KO2 clones. (B) DNA and protein sequences of control and DDR1 KO EMT6 cell clones. (C) There was no significant difference observed by cell proliferation assay in vitro between the DDR1 KO EMT6 cells and the control cells. (D and E) DDR1 KO significantly decreased tumor growth compared with the control group in vivo ( $\mathrm{n}=4$ per group). DDR1, discoidin domain receptor tyrosine kinase 1; KO, knockout; OD, optical density.

EMT6 cells were releasing DDR1-ECD in the media. Secreted soluble DDR1-ECD was detected in the conditioned media from EMT6 cells (Fig. 5A). It was, therefore, hypothesized that treatment with a DDR1 neutralizing antibody $(41,45)$, which specifically targets DDR1-ECD, could suppress tumor growth in vivo. To this end, parental EMT- 6 cells were inoculated in mice to form tumors, and then treated with either the DDR1 neutralizing antibody (EMT6/anti-DDR1 group) or an isotype IgG1 control antibody (EMT6/anti-IgG group). The tumors in the EMT6/anti-DDR1 group grew much slower than those in the EMT6/anti-IgG group (P<0.001; Fig. 5B and C). In addition, there were more $\mathrm{CD} 4^{+}$and $\mathrm{CD} 8^{+} \mathrm{T}$ cells in the tumors of the EMT6/anti-DDR1 group compared with those in the EMT6/anti-IgG group $(\mathrm{P}=0.03$ and $\mathrm{P}=0.018$, respectively; Fig. 5D and E).
DDRI mRNA is negatively correlated with the TIL signature gene expression. In order to further validate the impact of tumor cell DDR1 on antitumor immunity, TIMER (Tumor Immune Estimation Resource, http://cistrome.org/TIMER) (46), a comprehensive resource for the clinical relevance of tumor-immune cell correlations, was used to analyze TCGA breast cancer RNA sequencing dataset (27). It was revealed that the DDR1 mRNA expression levels were positively correlated with tumor purity, and negatively correlated with tumor infiltration of $\mathrm{CD}^{+}$and $\mathrm{CD}^{+} \mathrm{T}$ cells (Fig. 6A). Furthermore, DDR1 mRNA expression levels were negatively correlated with the TIL signature genes CD4 and CD8A, and the cytotoxic $\mathrm{T}$ cell marker granzyme B (Fig. 6B). Taken together, these data suggested that tumor cell DDR1 may affect tumor immunity in patients with breast cancer, which was consistent 

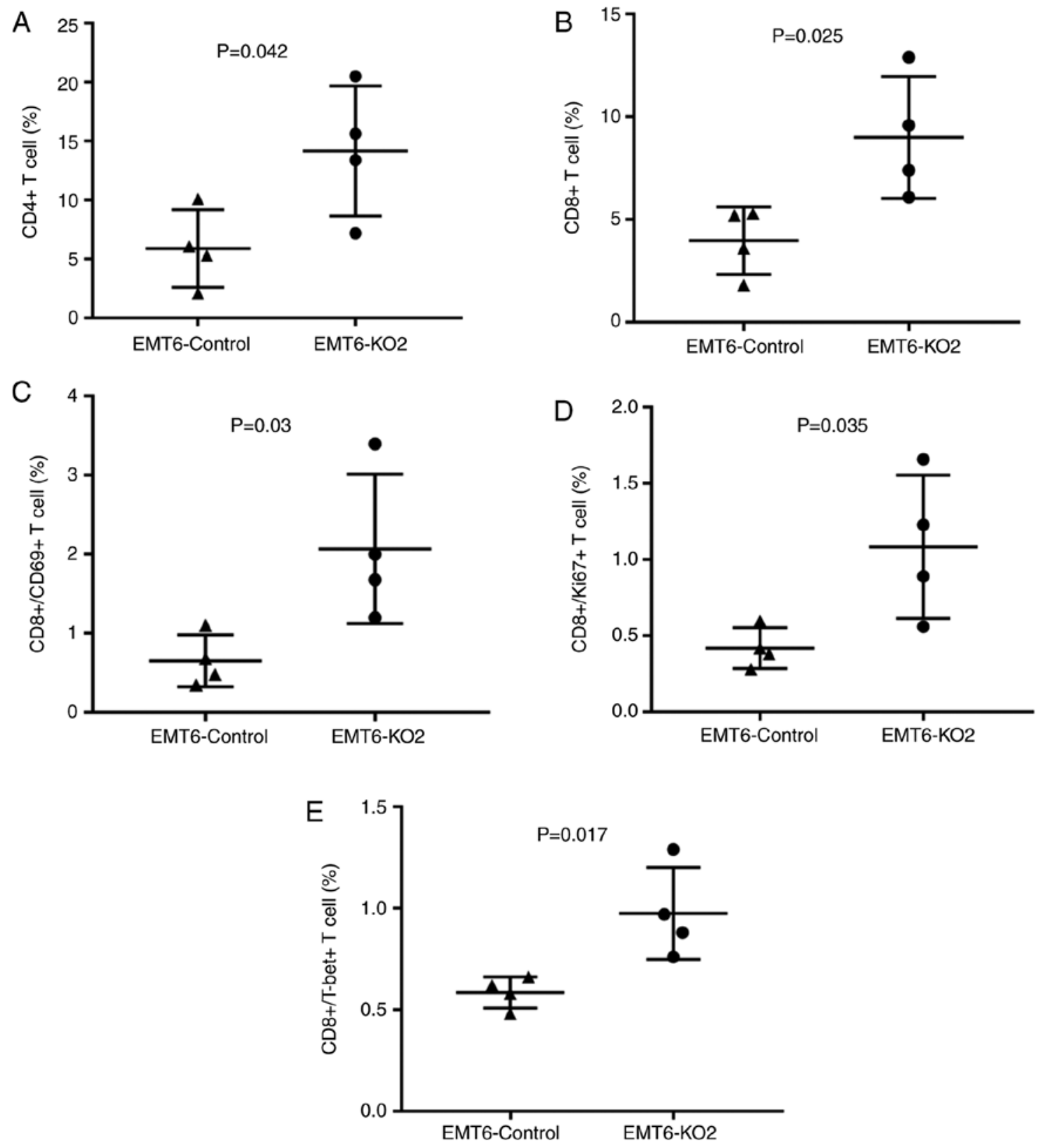

Figure 4. Deletion of DDR1 elicits a distinct immunophenotypic signature in EMT6 tumor-bearing mice. Flow cytometry analysis of dissociated tumors ( $\mathrm{n}=4$ per group) for the percentage of (A) $\mathrm{CD}^{+} \mathrm{T}$ cells, (B) $\mathrm{CD}^{+} \mathrm{T}$ cells, (C) early activated $\mathrm{CD} 8^{+} \mathrm{T}$ cells, (D) proliferative $\mathrm{CD} 8^{+} \mathrm{T}$ cells, and (E) $\mathrm{T}$-bet ${ }^{+} \mathrm{CD} 8^{+}$ infiltrating T cells. DDR1, discoidin domain receptor tyrosine kinase 1; T-bet, T-box transcription factor 21; KO, knockout.

with the conclusions obtained from the syngeneic mammary tumor models in the present study.

\section{Discussion}

DDR1 was originally identified during the search for tyrosine kinase proteins expressed in human malignancies (47-49). DDR1 kinase is different from other receptor tyrosine kinase (RTK) members due to a homology domain in discoidin (50). After two decades of study, it is now clear that aberrant signaling through the DDR1 is closely associated with different steps of tumorigenesis, although the detailed molecular mechanism underlying the role of DDR1 remains largely unknown. Several studies have demonstrated that knockdown of DDR1 with small interfering RNA or short hairpin RNA in human cancer cell lines leads to decreased cell proliferation and metastatic potential both in vitro and in vivo with immunodeficient mouse models $(16,51)$. However, mice with either whole body knockout of DDR1 or mammary gland specific deletion of DDR1 resulted in hyper-proliferation and abnormal branching of mammary ducts, and enhanced spontaneous tumorigenesis and lung metastasis $(52,53)$. Notably, DDR1 may serve different roles in the initiation and progression of breast cancer.

One recent study demonstrated that DDR1 mutations were strongly associated with poor prognosis in postmenopausal patients with breast cancer (25). Some of these DDR1 mutations are in the ECD domain, such as Q92fs, R93Q, R105Q and $\mathrm{N} 371 \mathrm{Y}$, but the biological significance of these require further investigation. 

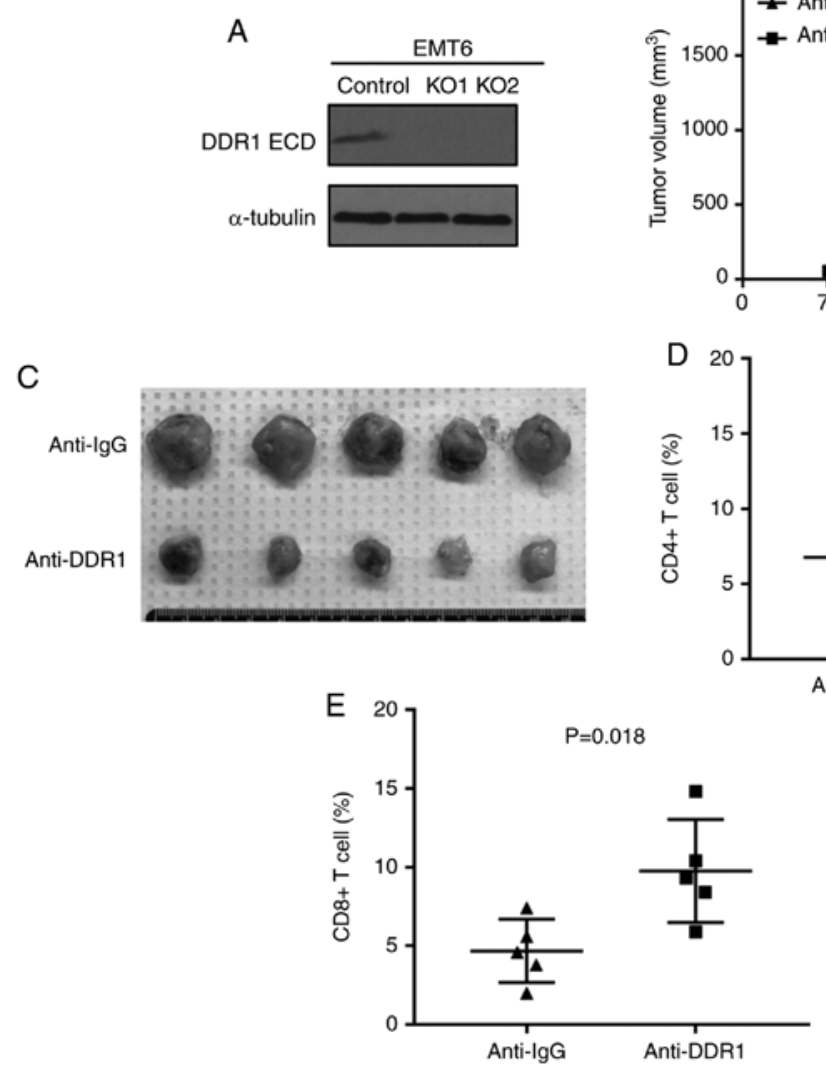
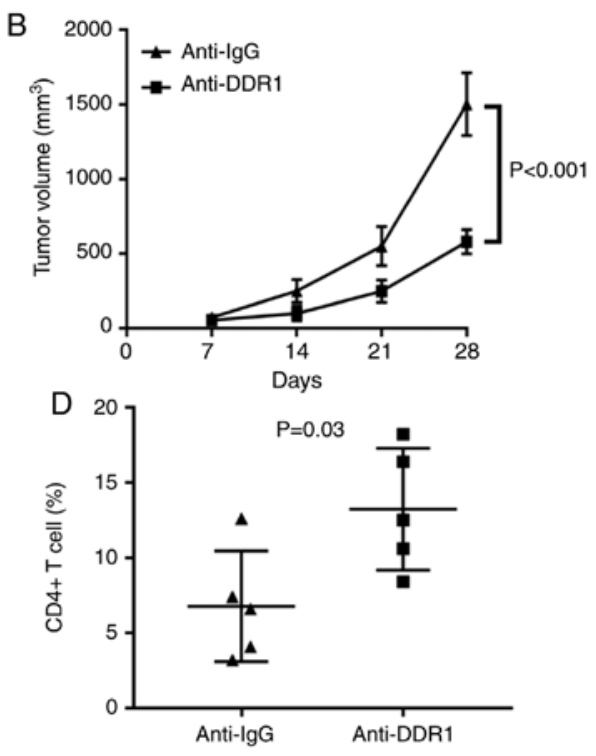

Figure 5. Effects of ECD neutralizing antibody on breast tumor growth in vivo. (A) Secreted DDR1-ECD protein was detected in the conditioned media of EMT6 cells by western blot analysis. (B and C) Tumor volumes and photographs of EMT6 cells in BALB/c nude mice treated with DR1-ECD neutralizing antibody or control IgG ( $\mathrm{n}=5$ per group). (D) Flow cytometry analysis of dissociated tumors ( $\mathrm{n}=5$ per group) for the percentage of $\mathrm{CD} 4^{+}$and $(\mathrm{E}) \mathrm{CD} 8^{+} \mathrm{T}$ cells ECD, extracellular domain; DDR1, discoidin domain receptor tyrosine kinase 1; IgG, immunoglobulin G; KO, knockout.

A
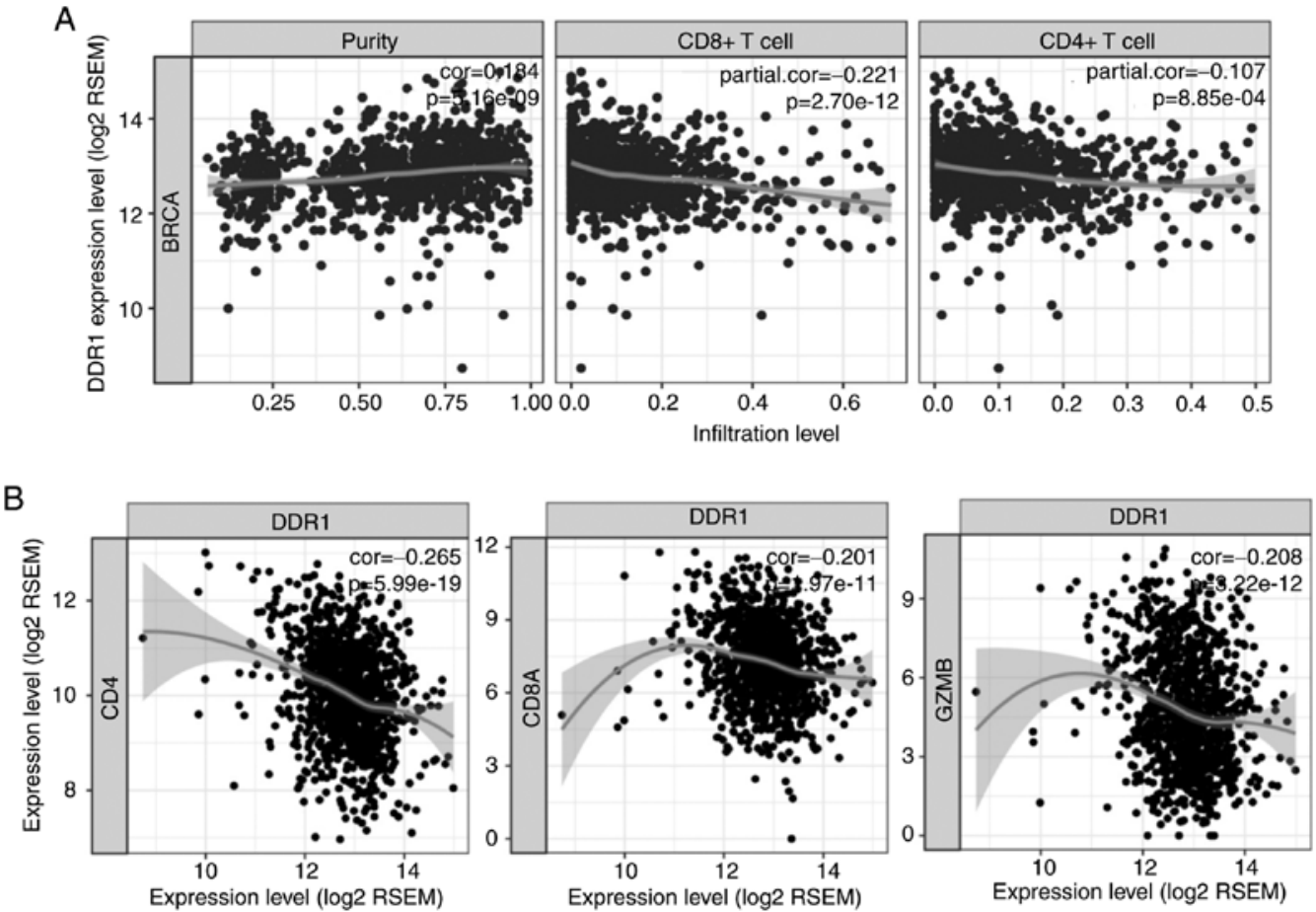

Figure 6. Correlation between DDR1 expression and immunity in TCGA breast cancer cohort. (A) Correlation between DDR1 mRNA expression levels and tumor purity $\left(\right.$ cor $\left.=0.184, \mathrm{P}=5.16 \times 10^{-9}\right), \mathrm{CD}^{+} \mathrm{T}$ cell count $\left(\right.$ cor $\left.=-0.221, \mathrm{P}=2.70 \times 10^{-12}\right)$ and $\mathrm{CD} 8^{+} \mathrm{T}$ cell count $\left(\right.$ cor $=-0.107$, $\left.\mathrm{P}=8.85 \times 10^{-4}\right)$. $(\mathrm{B}) \mathrm{Correlation}$ between DDR1 mRNA expression levels and tumor-infiltrating lymphocyte signature genes CD4 (cor=-0.265, $\left.\mathrm{P}=5.99 \times 10^{-19}\right)$ and $\mathrm{CD} 8 \mathrm{~A}\left(\mathrm{cor}=-0.201, \mathrm{P}=1.97 \times 10^{-11}\right)$, as well as the cytotoxic T cell marker GZMB (cor=-0.208, P=3.22x10 ${ }^{-12}$ ). DDR1, discoidin domain receptor tyrosine kinase 1; TCGA, The Cancer Genome Atlas; GZMB, granzyme B; BRCA, breast cancer. 
The detailed molecular mechanism underlying how tumor cell DDR1 promotes breast cancer progression remains unknown. To help drive this research forward, the present study used the 4T1 and EMT6 syngeneic breast tumor models. These models are derived from murine mammary carcinoma in $\mathrm{BALB} / \mathrm{c}$ mice and take advantage of the complete mouse immune system, serving as a powerful tool in immuno-oncology studies. Notably, the results from the present study demonstrated that DDR1 served a critical role in regulating tumor-immune cell interactions, in specific $\mathrm{CD} 4^{+}$and $\mathrm{CD} 8^{+} \mathrm{T}$ cells. However, how DDR1 regulates tumor infiltrated $\mathrm{T}$ cells is currently unknown. A previous study revealed functionally relevant interactions between DDR 1 and Notch1; DDR1 was important for Notch1 activation (54). Notch signaling controls $\mathrm{T}$ cell development, particularly for tumor-infiltrating $\mathrm{CD} 8^{+} \mathrm{T}$ cells $(55-57) . \mathrm{CD} 8^{+} \mathrm{T}$ cells have a critical role in establishing a sufficient immune response against cancer. Deletion or inhibition of DDR1 leads to inactivation of Notch signaling and stimulates the cytotoxic activation of TILs (57). The function-blocking anti-DDR1 antibody used in the present study was originally developed and tested in previous studies $(45,58)$. These previous studies found that the function-blocking anti-DDR1 antibody inhibits DDR1 signaling without interfering with collagen binding. In addition, it was demonstrated that the crystal structure of the monomeric DDR1-ECD bound to the Fab fragment of the antibody (58).

To the best of our knowledge, there are currently just two RTKs of which the ECD has been successfully allosterically targeted by small molecules: FGFR and DDR2 $(34,59,60)$. The present study demonstrated that inhibition of DDR1, using an ECD neutralizing antibody, decreased breast cancer growth in vivo by recruiting $\mathrm{CD} 4^{+}$and $\mathrm{CD} 8^{+}$TILs. This may represent a novel strategy to improve immunotherapy efficacy in breast cancer, even in TNBCs. During the preparation of the present manuscript, another study was published stating that there were more $\mathrm{CD} 8^{+} \mathrm{T}$ cells in tumors with depleted levels of DDR2, the other discoidin domain receptor family member (61). Furthermore, DDR2 depletion in isogenic murine models increased sensitivity to anti-programmed cell death 1 treatment when compared with monotherapy (61).

According to current studies, DDR1 has both kinasedependent and independent functions in cancer $(16,17,62-68)$. The present study highlighted a thus far unreported role of DDR1 in breast cancer progression, whereby DDR1 may elicit a tumor-promoting activity through modulating TILs. Therefore, DDR1 may serve as a potential target to improve efficiency of cancer immunotherapy. In future clinical studies, it would be meaningful if DDR1 expression levels were recorded in relation to patients' response to cancer immunotherapy in breast cancer, or other types of cancer.

\section{Acknowledgements}

Not applicable.

\section{Funding}

The present study was supported by the Project of Health Commission of Jiangxi province (grant no. 20175524).

\section{Availability of data and materials}

The datasets used and/or analyzed during the present study are available from the corresponding author upon reasonable request.

\section{Authors' contributions}

$\mathrm{XZ}$ conceived and supervised the project. WZ, TS and XZ performed the experiments and analyzed the data. WZ and $\mathrm{XZ}$ wrote the manuscript. All authors read and approved the final manuscript.

\section{Ethics approval and consent to participate}

Protocols involving the use of human tissue were approved by the Ethics Committee of Jiangxi Cancer Hospital and performed in accordance with the Declaration of Helsinki and the guidelines of the Ethics Committee of Jiangxi cancer Hospital. Written informed consent was obtained from all patients for the use of their tissues. Protocols involving animals were performed in accordance with the National Institute of Health Guide for the Care and Use of Laboratory Animals, with the approval of the Ethics Committee of Jiangxi Cancer Hospital.

\section{Patient consent for publication}

Not applicable.

\section{Competing interests}

The authors declare that they have no competing interests.

\section{References}

1. Bray F, Ferlay J, Soerjomataram I, Siegel RL, Torre LA and Jemal A: Global cancer statistics 2018: GLOBOCAN estimates of incidence and mortality worldwide for 36 cancers in 185 countries. CA Cancer J Clin 68: 394-424, 2018.

2. Podo F, Buydens LM, Degani H, Hilhorst R, Klipp E, Gribbestad IS, Van Huffel S, van Laarhoven HW, Luts J, Monleon D, et al: Triple-negative breast cancer: Present challenges and new perspectives. Mol Oncol 4: 209-229, 2010.

3. Palucka K and Banchereau J: Dendritic-cell-based therapeutic cancer vaccines. Immunity 39: 38-48, 2013.

4. Sahin U and Tureci O: Personalized vaccines for cancer immunotherapy. Science 359: 1355-1360, 2018.

5. June $\mathrm{CH}$, O'Connor RS, Kawalekar OU, Ghassemi S and Milone MC: CAR T cell immunotherapy for human cancer. Science 359: 1361-1365, 2018.

6. Hodi FS, O'Day SJ, McDermott DF, Weber RW, Sosman JA, Haanen JB, Gonzalez R, Robert C, Schadendorf D, Hassel JC, et al: Improved survival with ipilimumab in patients with metastatic melanoma. N Engl J Med 363: 711-723, 2010.

7. Wolchok JD, Kluger H, Callahan MK, Postow MA, Rizvi NA Lesokhin AM, Segal NH, Ariyan CE, Gordon RA, Reed K, et al: Nivolumab plus ipilimumab in advanced melanoma. N Engl J Med 369: 122-133, 2013.

8. Postow MA, Chesney J, Pavlick AC, Robert C, Grossmann K, McDermott D, Linette GP, Meyer N, Giguere JK, Agarwala SS, et al: Nivolumab and ipilimumab versus ipilimumab in untreated melanoma. N Engl J Med 372: 2006-2017, 2015.

9. Adams S, Gray RJ, Demaria S, Goldstein L, Perez EA, Shulman LN, Martino S, Wang M, Jones VE, Saphner TJ, et al: Prognostic value of tumor-infiltrating lymphocytes in triple-negative breast cancers from two phase III randomized adjuvant breast cancer trials: ECOG 2197 and ECOG 1199. J Clin Oncol 32: 2959-2966, 2014. 
10. Ali HR, Provenzano E, Dawson SJ, Blows FM, Liu B, Shah M, Earl HM, Poole CJ, Hiller L, Dunn JA, et al: Association between CD8+ T-cell infiltration and breast cancer survival in 12,439 patients. Ann Oncol 25: 1536-1543, 2014.

11. Loi S, Michiels S, Salgado R, Sirtaine N, Jose V, Fumagalli D, Kellokumpu-Lehtinen PL, Bono P, Kataja V, Desmedt C, et al: Tumor infiltrating lymphocytes are prognostic in triple negative breast cancer and predictive for trastuzumab benefit in early breast cancer: Results from the FinHER trial. Ann Oncol 25: 1544-1550, 2014.

12. Emens LA: Breast cancer immunotherapy: Facts and hopes. Clin Cancer Res 24: 511-520, 2018.

13. Vonderheide RH, Domchek SM and Clark AS: Immunotherapy for breast cancer: What are we missing? Clin Cancer Res 23: 2640-2646, 2017.

14. Nanda R, Chow LQ, Dees EC, Berger R, Gupta S, Geva R, Pusztai L, Pathiraja K, Aktan G, Cheng JD, et al: Pembrolizumab in patients with advanced triple-negative breast cancer: Phase $\mathrm{Ib}$ KEYNOTE-012 study. J Clin Oncol 34: 2460-2467, 2016.

15. Weiner HL, Huang H, Zagzag D, Boyce H, Lichtenbaum R and Ziff EB: Consistent and selective expression of the discoidin domain receptor-1 tyrosine kinase in human brain tumors Neurosurgery 47: 1400-1409, 2000.

16. Jin H, Ham IH, Oh HJ, Bae CA, Lee D, Kim YB, Son SY, Chwae YJ, Han SU, Brekken RA and Hur H: Inhibition of discoidin domain receptor 1 prevents stroma-induced peritoneal metastasis in gastric carcinoma. Mol Cancer Res 16: 1590-1600, 2018.

17. Ambrogio C, Gómez-López G, Falcone M, Vidal A, Nadal E, Crosetto N, Blasco RB, Fernández-Marcos PJ, Sánchez-Céspedes M, Ren X, et al: Combined inhibition of DDR1 and Notch signaling is a therapeutic strategy for KRAS-driven lung adenocarcinoma. Nat Med 22: 270-277, 2016.

18. Heinzelmann-Schwarz VA, Gardiner-Garden M, Henshall SM Scurry J, Scolyer RA, Davies MJ, Heinzelmann M, Kalish LH, Bali A, Kench JG, et al: Overexpression of the cell adhesion molecules DDR1, Claudin 3, and Ep-CAM in metaplastic ovarian epithelium and ovarian cancer. Clin Cancer Res 10: 4427-4436, 2004

19. Park HS, Kim KR, Lee HJ, Choi HN, Kim DK, Kim BT and Moon WS: Overexpression of discoidin domain receptor 1 increases the migration and invasion of hepatocellular carcinoma cells in association with matrix metalloproteinase. Oncol Rep 18: $1435-1441,2007$.

20. Yamanaka R, Arao T, Yajima N, Tsuchiya N, Homma J, Tanaka R, Sano M, Oide A, Sekijima M and Nishio K: Identification of expressed genes characterizing long-term survival in malignant glioma patients. Oncogene 25: 5994-6002, 2006

21. Shen Q, Cicinnati VR, Zhang X, Iacob S, Weber F, Sotiropoulos GC, Radtke A, Lu M, Paul A, Gerken G and Beckebaum S: Role of microRNA-199a-5p and discoidin domain receptor 1 in human hepatocellular carcinoma invasion. Mol Cancer 9: 227, 2010.

22. Rudd ML, Mohamed H, Price JC, O'Hara AJ, Le Gallo M, Urick ME; NISC Comparative Sequencing Program, Cruz P, Zhang S, Hansen NF, et al: Mutational analysis of the tyrosine kinome in serous and clear cell endometrial cancer uncovers rare somatic mutations in TNK2 and DDR1. BMC Cancer 14: 884 2014.

23. Loriaux MM, Levine RL, Tyner JW, Fröhling S, Scholl C, Stoffregen EP, Wernig G, Erickson H, Eide CA, Berger R, et al: High-throughput sequence analysis of the tyrosine kinome in acute myeloid leukemia. Blood 111: 4788-4796, 2008.

24. Ding L, Getz G, Wheeler DA, Mardis ER, McLellan MD, Cibulskis K, Sougnez C, Greulich H, Muzny DM, Morgan MB, et al: Somatic mutations affect key pathways in lung adenocarcinoma. Nature 455: 1069-1075, 2008.

25. Griffith OL, Spies NC, Anurag M, Griffith M, Luo J, Tu D, Yeo B, Kunisaki J, Miller CA, Krysiak K, et al: The prognostic effects of somatic mutations in ER-positive breast cancer. Nat Commun 9: 3476, 2018

26. Agnihotri S, Jalali S, Wilson MR, Danesh A, Li M, Klironomos G, Krieger JR, Mansouri A, Khan O, Mamatjan Y, et al: The genomic landscape of schwannoma. Nat Genet 48: 1339-1348, 2016.

27. Cancer Genome Atlas Network: Comprehensive molecular portraits of human breast tumours. Nature 490: 61-70, 2012.

28. Chandrashekar DS, Bashel B, Balasubramanya SAH, Creighton CJ, Ponce-Rodriguez I, Chakravarthi BVSK and Varambally S: UALCAN: A portal for facilitating tumor subgroup gene expression and survival analyses. Neoplasia 19: 649-658, 2017
29. Prykhozhij SV, Rajan V, Gaston D and Berman JN: CRISPR multitargeter: A web tool to find common and unique CRISPR single guide RNA targets in a set of similar sequences. PLoS One 10: e0119372, 2015

30. O'Brien A and Bailey TL: GT-Scan: Identifying unique genomic targets. Bioinformatics 30: 2673-2675, 2014.

31. Xu L, Jensen H, Johnston JJ, Di Maria E, Kloth K, Cristea I, Sapp JC, Darling TN, Huryn LA, Tranebjærg L, et al: Recurrent, activating variants in the receptor tyrosine kinase DDR2 cause warburg-cinotti syndrome. Am J Hum Genet 103: 976-983, 2018.

32. Livak KJ and Schmittgen TD: Analysis of relative gene expression data using real-time quantitative PCR and the 2(-Delta Delta C(T)) method. Methods 25: 402-408, 2001

33. Klionsky DJ, Abdelmohsen K, Abe A, Abedin MJ, Abeliovich $\mathrm{H}$, Acevedo Arozena A, Adachi H, Adams CM, Adams PD, Adeli K, et al: Guidelines for the use and interpretation of assays for monitoring autophagy (3rd edition). Autophagy 12: 1-222, 2016.

34. Grither WR and Longmore GD: Inhibition of tumor-microenvironment interaction and tumor invasion by small-molecule allosteric inhibitor of DDR2 extracellular domain. Proc Natl Acad Sci USA 115: E7786-E7794, 2018.

35. Wherry EJ and Kurachi M: Molecular and cellular insights into T cell exhaustion. Nat Rev Immunol 15: 486-499, 2015.

36. Mori H, Kubo M, Kai M, Yamada M, Kurata K, Kawaji H, Kaneshiro K, Osako T, Nishimura R, Arima N, et al: T-bet ${ }^{+}$ lymphocytes infiltration as an independent better prognostic indicator for triple-negative breast cancer. Breast Cancer Res Treat 176: 569-577, 2019.

37. Alves F, Vogel W, Mossie K, Millauer B, Höfler H and Ullrich A: Distinct structural characteristics of discoidin I subfamily receptor tyrosine kinases and complementary expression in human cancer. Oncogene 10: 609-618, 1995.

38. Vogel W: Discoidin domain receptors: Structural relations and functional implications. FASEB J 13 (Suppl): S77-S82, 1999.

39. Leitinger B: Discoidin domain receptor functions in physiological and pathological conditions. Int Rev Cell Mol Biol 310: 39-87, 2014

40. Canning P, Tan L, Chu K, Lee SW, Gray NS and Bullock AN: Structural mechanisms determining inhibition of the collagen receptor DDR1 by selective and multi-targeted type II kinase inhibitors. J Mol Biol 426: 2457-2470, 2014.

41. Gao H, Chakraborty G, Zhang Z, Akalay I, Gadiya M, Gao Y, Sinha S, Hu J, Jiang C, Akram M, et al: Multi-organ site metastatic reactivation mediated by non-canonical discoidin domain receptor 1 signaling. Cell 166: 47-62, 2016.

42. Yeung D, Chmielewski D, Mihai C and Agarwal G: Oligomerization of DDR1 ECD affects receptor-ligand binding. J Struct Biol 183: 495-500, 2013.

43. Leitinger B: Molecular analysis of collagen binding by the human discoidin domain receptors, DDR1 and DDR2. Identification of collagen binding sites in DDR2. J Biol Chem 278: 16761-16769, 2003.

44. Fu HL, Sohail A, Valiathan RR, Wasinski BD, Kumarasiri M, Mahasenan KV, Bernardo MM, Tokmina-Roszyk D, Fields GB, Mobashery S and Fridman R: Shedding of discoidin domain receptor 1 by membrane-type matrix metalloproteinases. J Biol Chem 288: 12114-12129, 2013.

45. Carafoli F, Mayer MC, Shiraishi K, Pecheva MA, Chan LY, Nan R, Leitinger B and Hohenester E: Structure of the discoidin domain receptor 1 extracellular region bound to an inhibitory Fab fragment reveals features important for signaling. Structure 20: 688-697, 2012

46. Li T, Fan J, Wang B, Traugh N, Chen Q, Liu JS, Li B and Liu XS: TIMER: A web server for comprehensive analysis of tumor-infiltrating immune cells. Cancer Res 77: e108-e110, 2017.

47. Johnson JD, Edman JC and Rutter WJ: A receptor tyrosine kinase found in breast carcinoma cells has an extracellular discoidin I-like domain. Proc Natl Acad Sci USA 90: 5677-5681, 1993.

48. Di Marco E, Cutuli N, Guerra L, Cancedda R and De Luca M: Molecular cloning of trkE, a novel trk-related putative tyrosine kinase receptor isolated from normal human keratinocytes and widely expressed by normal human tissues. J Biol Chem 268 : 24290-24295, 1993.

49. Zerlin M, Julius MA and Goldfarb M: NEP: A novel receptor-like tyrosine kinase expressed in proliferating neuroepithelia. Oncogene 8: 2731-2739, 1993. 
50. Kiedzierska A, Smietana K, Czepczynska H and Otlewski J: Structural similarities and functional diversity of eukaryotic discoidin-like domains. Biochim Biophys Acta 1774: 1069-1078, 2007.

51. Yuge R, Kitadai Y, Takigawa H, Naito T, Oue N, Yasui W, Tanaka $\mathrm{S}$ and Chayama $\mathrm{K}$ : Silencing of discoidin domain receptor-1 (DDR1) concurrently inhibits multiple steps of metastasis cascade in gastric cancer. Transl Oncol 11: 575-584, 2018

52. Vogel WF, Aszodi A, Alves F and Pawson T: Discoidin domain receptor 1 tyrosine kinase has an essential role in mammary gland development. Mol Cell Biol 21: 2906-2917, 2001.

53. Takai K, Drain AP, Lawson DA, Littlepage LE, Karpuj M, Kessenbrock K, Le A, Inoue K, Weaver VM and Werb Z: Discoidin domain receptor 1 (DDR1) ablation promotes tissue fibrosis and hypoxia to induce aggressive basal-like breast cancers. Genes Dev 32: 244-257, 2018.

54. Kim HG, Hwang SY, Aaronson SA, Mandinova A and Lee SW: DDR1 receptor tyrosine kinase promotes prosurvival pathway through Notch1 activation. J Biol Chem 286: 17672-17681, 2011.

55. Kuijk LM, Verstege MI, Rekers NV, Bruijns SC, Hooijberg E, Roep BO, de Gruijl TD, van Kooyk Y and Unger WW: Notch controls generation and function of human effector CD8+ T cells Blood 121: 2638-2646, 2013.

56. Cho OH, Shin HM, Miele L, Golde TE, Fauq A, Minter LM and Osborne BA: Notch regulates cytolytic effector function in CD8+ T cells. J Immunol 182: 3380-3389, 2009.

57. Yu W, Wang Y and Guo P: Notch signaling pathway dampens tumor-infiltrating $\mathrm{CD} 8^{+} \mathrm{T}$ cells activity in patients with colorectal carcinoma. Biomed Pharmacother 97: 535-542, 2018.

58. Juskaite V, Corcoran DS and Leitinger B: Collagen induces activation of DDR1 through lateral dimer association and phosphorylation between dimers. Elife 6: pii: e25716, 2017.

59. Bono F, De Smet F, Herbert C, De Bock K, Georgiadou M, Fons P, Tjwa M, Alcouffe C, Ny A, Bianciotto M, et al: Inhibition of tumor angiogenesis and growth by a small-molecule multi-FGF receptor blocker with allosteric properties. Cancer Cell 23: 477-488, 2013

60. Herbert C, Schieborr U, Saxena K, Juraszek J, De Smet F, Alcouffe C, Bianciotto M, Saladino G, Sibrac D, Kudlinzki D, et al: Molecular mechanism of SSR128129E, an extracellularly acting, small-molecule, allosteric inhibitor of FGF receptor signaling. Cancer Cell 23: 489-501, 2013.
61. Tu MM, Lee FYF, Jones RT, Kimball AK, Saravia E, Graziano RF, Coleman B, Menard K, Yan J, Michaud E, et al: Targeting DDR2 enhances tumor response to anti-PD-1 immunotherapy. Sci Adv 5: eaav2437, 2019.

62. Tao Y, Wang R, Lai Q, Wu M, Wang Y, Jiang X, Zeng L, Zhou S, Li Z, Yang T, et al: Targeting of DDR1 with antibody-drug conjugates has antitumor effects in a mouse model of colon carcinoma. Mol Oncol: May 22, 2019 (Epub ahead of print).

63. Vehlow A, Klapproth E, Jin S, Hannen R, Hauswald M, Bartsch JW, Nimsky C, Temme A, Leitinger B and Cordes $\mathrm{N}$ : Interaction of discoidin domain receptor 1 with a 14-3-3-Beclin-1-Akt1 complex modulates glioblastoma therapy sensitivity. Cell Rep 26: 3672-3683.e7, 2019.

64. Aguilera KY, Huang H, Du W, Hagopian MM, Wang Z, Hinz S, Hwang TH, Wang H, Fleming JB, Castrillon DH, et al: Inhibition of discoidin domain receptor 1 reduces collagen-mediated tumorigenicity in pancreatic ductal adenocarcinoma. Mol Cancer Ther 16: 2473-2485, 2017

65. Lu QP, Chen WD, Peng JR, Xu YD, Cai Q, Feng GK, Ding K, Zhu XF and Guan Z: Antitumor activity of $7 \mathrm{RH}$, a discoidin domain receptor 1 inhibitor, alone or in combination with dasatinib exhibits antitumor effects in nasopharyngeal carcinoma cells. Oncol Lett 12: 3598-3608, 2016

66. Shitomi Y, Thogersen IB, Ito N, Leitinger B, Enghild JJ and Itoh Y: ADAM10 controls collagen signaling and cell migration on collagen by shedding the ectodomain of discoidin domain receptor 1 (DDR1). Mol Biol Cell 26: 659-673, 2015.

67. Gao M, Duan L, Luo J, Zhang L, Lu X, Zhang Y, Zhang Z, Tu Z, Xu Y, Ren X and Ding K: Discovery and optimization of 3-(2-(Pyrazolo[1,5-a]pyrimidin-6-yl)ethynyl)benzamides as novel selective and orally bioavailable discoidin domain receptor 1 (DDR1) inhibitors. J Med Chem 56: 3281-3295, 2013.

68. Ali-Rahmani F, FitzGerald DJ, Martin S, Patel P, Prunotto M, Ormanoglu P, Thomas C and Pastan I: Anticancer effects of mesothelin-targeted immunotoxin therapy are regulated by tyrosine kinase DDR1. Cancer Res 76: 1560-1568, 2016. 